\title{
Dimensions of Digital B2B Platforms in Logistics - A White Spot Analysis
}

\author{
Carina Culotta \\ Fraunhofer Institute for Material Flow and Logistics \\ carina.culotta@iml.fraunhofer.de
}

\author{
Estelle Duparc \\ TU Dortmund University \\ estelle.duparc@tu-dortmund.de
}

\begin{abstract}
Digital platforms have not only transformed entire B2C market segments but also created new markets benefiting from indirect network effects by providing technological building blocks and infrastructure. Digital platforms and according business models can also be found in the B2B context. Especially, logistics seems to be an adequate application for digital, platform-based business models. The present article focuses on B2B logistics platforms and questions whether principles of $B 2 C$ platforms can be transferred to the domain of logistics. In order to assess the transferability of B2C platform characteristics, a white spot analysis is conducted along a sample of 54 digital platforms. The goal of the white spot analysis is to provide insights into the characteristics of digital B2B platforms in logistics. Moreover, the analysis provides a basis for the discussion whether B2C platform principles can be adopted in an industrial context.
\end{abstract}

\section{Introduction}

Digital platform businesses such as Apple, Amazon, Uber and Airbnb have transformed existing business models and altered entire market structures $[1,2]$. However, these prominent platform examples are considered to be $\mathrm{B} 2 \mathrm{C}$ - or $\mathrm{C} 2 \mathrm{C}$ platforms. Digital platforms in the industry and $\mathrm{B} 2 \mathrm{~B}$ sector are much less studied and represented in the academic literature [3]. Such an underrepresentation in the literature may be linked to the slow rate of real-world dissemination and the challenges companies experience when establishing business platforms. Companies joining a digital platform, perceive platform participation to be a greater risk compared to consumers in the $\mathrm{B} 2 \mathrm{C}$ - or C2C context [3-5].

Therefore, platform orchestrators have to engage much more in trust-building between participants in order to motivate them to join the platform [3]. Likewise, platform orchestrators have to recognize competing concerns between platform participants [6] and possess profound industry and ecosystem knowledge in order to be successful [7, 8]. Moreover, B2B platform creators need to take into account crossindustry challenges and ensure commitment of platform partners to the value-co-creation process [4].

While traditional industries struggle or are hesitant to build own platforms, it can be observed that traditional platform businesses rush into those markets transferring $\mathrm{B} 2 \mathrm{C}$ - or $\mathrm{C} 2 \mathrm{C}$ market strategies into new B2B segments. This holds to be true especially for the logistics sector: Amongst others, established platforms such as Amazon and Uber get a foothold in the B2B logistics market [9]. As such, Amazon builds own transportation networks and offers industrial freight exchanges [10]. Moreover, B2B platforms in logistics are used in order to allocate resources effectively and provide additional services for customers like status monitoring of shipped goods and services linked with estimated time of arrival. Moreover, freight exchanges and matching of drivers or unused storage are depicted on platforms [11]. However, those platforms described and assessed are mostly so-called transaction platforms facilitating transactions and the exchange of information, goods and services.

Consequently, the literature focuses on ecommerce and the resulting impact on logistics [1215] or simple transaction platforms and the transformation of the market with respect to e.g. fourth-party logistics (hereafter 4PL) service providers $[11,16,17]$. Few papers have partially addressed specific characteristics and challenges of B2B platforms in logistics such as [9], [17] and [18]. However, they do not distinguish between platform types or questions the extent to which $\mathrm{B} 2 \mathrm{C}$ principles can be transferred. Unlike transaction platforms, a lot of $\mathrm{B} 2 \mathrm{C}$ platforms can be described as innovation platforms providing technology and infrastructure linking external and non-contractually organized third-party provision of complementary (digital) goods and services. Given the focus in the existing literature and the impression that mostly transaction platforms and e-commerce platforms are observed in logistics, the underlying paper poses the following research question: 
Research Question: To which extent can B2C platforms principles be observed in a B2B platform context in logistics?

Thereby, the paper is structured as follows: The next respectively second section lays the theoretical basis for digital platforms and their characteristics. The third section links digital platforms with logistics. The fourth section deals with a white spot analysis of logistics platforms and matches logistical tasks with platform characteristics identified in the B2C literature. The paper closes with a discussion of the findings and provides and outlook for further research.

\section{Theoretical Foundations of Digital Platforms and Ecosystems}

In general, digital platforms reduce transaction costs and facilitate interaction between different parties that would otherwise not have interacted. Digital platforms thereby build upon direct and indirect network effects. In their seminal work [19, 20] propose the theory of network externalities which is widely cited in the context of platform economics. In specific, [19] show that positive consumption externalities emerge when users benefit from the adoption of other users of the same product. One prominent example for instances is the telephone, whose value is dependent on the number of users. As more users use a telephone, the more attractive it is for further users to buy a telephone. Those network externalities can also be transferred to markets consisting of firms that produce interlinked products such as software and hardware. If compatibility is given, suppliers and consumers will benefit from positive network externalities [20]. However, coordination and achievement of compatibility is not only difficult but costly and have to be considered with respect to competitive advantages [20].

Digital platforms however, provide such a coordination. At first of all, direct network effects as in the case of the telephone describe the utility users derive from the interaction with other users respectively the platform owner itself [21]. A more current example would be social networks providing value for users by allowing interaction between them. At the same time, digital platforms can enforce indirect network effects respectively network externalities in the sense of [19] by opening up their technology to external firms. By the provision of technological building blocks, external firms and programmers can develop goods and services that complement the original value proposition of the focal firm [22]. Basically, indirect network effects entail that the more complementary goods and services are attached to the original platform, the more users will be attracted to join the platform leading to the attraction of further complementary providers [23, 24]. In the case of social networks this would for instances imply the incorporation of additional features such as games or advertisement. Consequently, indirect network effects do not only explain why platforms are successful but also why platforms benefit from increasing returns to scale and thus have a tendency for monopolization respectively market-tipping occurring against the background of far-reaching network effects [2, 25].

Thereof, platforms can be characterized either as two-sided platforms or multisided platforms [25]. Platforms bringing together two market sides can be seen as two-sided platforms whereas platforms that connect for instances third-party sellers as an additional platform participant can be seen as multisided platforms [26]. On the basis of these observations [2] and [27] characterize digital platforms either as a transaction platform or as an innovation platform. The main purpose of transaction platforms is to facilitate the exchange of information, services or goods between different platform participants [2]. Examples for transaction platforms are platforms that act as intermediaries such as market places like eBay or social networks like Twitter. However, innovation platforms create value by enabling the joint creation of innovation by providing technological building blocks rendering possible the provision and emergence of complementary products and services [2]. On the basis of such technological building blocks such as application programming interfaces (hereafter APIs) or access to software development kits, other firms can develop and provide new products and services [28]. Such complementary goods or services add value to the modular character of the platform by contributing additional soft- or hardware that complements the original product and thereby enforce indirect network effects [29]. One prominent example is the App Store, as Apple's smartphones would be rather unattractive without applications. Hence, innovation platform providers do not only provide technological infrastructure but become orchestrators of ecosystems. In general, an ecosystem can be defined as "[...] a group of interacting firms that depend on each other's activities" [30 p. 2]. Thereby, ecosystems require complementary innovations that may come from different industries and are not bound to contractual agreements [30]. Consequently, digital platforms incorporating complementary products and services can be seen as digital ecosystems with the focal platform being the orchestrator [31, 32]. Besides transaction- and innovation platforms, hybrid 
platforms do also exist. Those are platforms that incorporate elements of transaction platforms as well as innovation platforms. General examples are Google and Facebook as they do not only allow for transactions but also provide technological modules for further applications [27].

Generally, the empirical basis for analysis of digital platforms and ecosystems are often B2C- or C2C platforms drawing on examples from video game industry [33], private transportation and accommodation or e-commerce, consumer goods and social networks [31, 34].

\section{Digital Platforms in Logistics}

Logistical tasks are essential elements of almost every business and can often be seen as a key factor for economic success of many firms. There are numerous concepts of logistics and the according tasks. The Council of Supply Chain Management Professionals currently defines logistics management as following: "Logistics management is that part of supply chain management that plans, implements, and controls the efficient, effective forward and reverses flow and storage of goods, services and related information between the point of origin and the point of consumption in order to meet customers' requirements" [35]. Thereby, logistics can be divided into different domains being supply logistics, intraand production logistics, distribution logistics and reverse logistics [36]. Within each domain, different tasks have to be fulfilled and can supported by various tools and technologies such as cyber-physical systems or cloud computing.

On a very essential level, [37 p. 6] name those key tasks of logistics to be:

- $\quad$ Storage, warehousing and materials handling

- Packaging and unitization

- Inventory

- (Freight) Transport

- Information and control.

Similarly, [36] name the same logistics tasks but distinguish between storage and warehousing and add order picking and materials handling as explicit tasks.

From an economic-theoretical point of view, the purposes and tasks of logistics and supply chain management can be explained by different theories such as transaction cost economics and network theory. Amongst others, transaction costs economics explains why firms outsource logistical tasks to logistics service providers [38-40]. Managing only one relationship with only one third-party logistics (hereafter 3PL) provider is often less costly in terms of transaction costs than managing several direct relationships with customers [40]. Similarly, [41] emphasize the reduction of transaction costs as a major criterion to outsource logistical activities to 3PL providers. Likewise, network theory helps to explain why 3PL providers are also meant to manage relationships between customers and interacting firms during the logistical process [40]. Consequently, logistics can be seen as a tool to reduce transaction costs and increase efficiency and transparency between interacting parties [40]. At the same time, network theory and transaction cost economics are also amongst others foundations for theoretical considerations of digital platforms [2, 42]. Given a common theoretical basis for logistics as a network coordinator and the purpose to reduce transaction costs, it may be standing to reason that logistics as a task and as an industry is predestined to be an appropriate field of application for digital platforms.

Thereby, digital platforms in logistics seem to be driven by start-ups as [43] and [18, 44] show. The most common types of platforms in logistics are freight exchanges, comparison and booking portals and digital forwarders $[18,44]$. Based on the circumstance that start-ups seem to transform the logistics market, [43] analyze and identify five different archetypes of business models. Four out of five business models are platform-based, such as booking platforms for transportation or digital markets for warehousing services. The role of start-ups and 4PL-related business models as a challenge for traditional $3 \mathrm{PL}$ is also discussed by [9]. Thereby, [9] recognize that platform-based business models are on the one hand a threat for 3PL providers but at the same time have a tremendous potential as well. In addition, [18] and [9] note that traditional logistics providers who focus on standardization will be likely to lose market shares as additional digital services and the integration into individual supply chains of customers are experiencing an increasing demand. Therefore, 3PL providers should not solely focus on standardization but try to benefit from the underlying advantages of platforms. Furthermore, [9] suggest that 3PL can benefit from collaborative consumption as 3PL providers can reduce costs by efficient usage of assets allowing for more capacities in order to develop additional digital assets and services. Moreover, [9] implicitly suggest that 3PL logistics providers could benefit from providing technological infrastructure and thereby integrating complementary goods and services resulting in additional business opportunities due to indirect network effects.

Rather from a user- than from a providing perspective, [17] discuss criteria for joining digital, yet existing freight platforms from the viewpoint of 3PL providers. Thus, the authors do not elaborate on the 
potentials of creating platforms for 3PL per se but describe the characteristics and functioning principals of digital B2B platforms. Based on their empirical findings, [17] identify different potentials and likewise risks associated with joining a platform from the viewpoint of logistics service providers. The main opportunity related with freight platforms, is the increase in efficiency due to the underlying matching mechanisms and reduction in search costs [17]. Moreover, trust can be established by gatekeeping mechanisms as a basis for collaboration via the platform [17]. However, [17] find that logistics service providers are hesitant to use platforms as they fear dependencies on the platform and respective lock-in effects due to reduced contact to customers. Moreover, [17] observe that costly add-ins for platform integration are hampering platform adoption. Therefore, [16] and [11] also suggest that 4PL providers whose business model is centered around an IT platform should ensure easy integration allowing value creation by providing additional services.

Consequently, digital platforms are described and can be found in the field of logistics. However, as already pointed out, tools and characteristics to describe digital platforms in logistics are borrowed from $\mathrm{B} 2 \mathrm{C}-$ and $\mathrm{C} 2 \mathrm{C}$ platform literature.

Therefore, the following section deals with the analysis of platforms in logistics by questioning whether B2C principles can be fully transferred or applied in order to describe B2B platforms in logistics.

\section{White Spot Analysis}

In order to assess, to which extent $\mathrm{B} 2 \mathrm{C}$ - or $\mathrm{C} 2 \mathrm{C}$ platform characteristics can be found and respectively transferred to the B2B logistics domain, a white spot analysis is conducted. The white spot analysis allows for an empirical analysis. Thereby conceptional frameworks can either be confirmed or challenged by the empirical findings demonstrating eventual shortcomings. Likewise, new avenues or support for theoretical frameworks can be derived. In order to construct a useful framework for analyzing platforms and logistical tasks, respective dimensions were derived from the literature discussed above. In a next step, the first collection of possible dimensions was challenged against the sample set of digital platforms. In this way, it is ensured that the selected dimension serve the purpose. During this process, some of the initial categories were omitted in order to facilitate the subsequent white spot analysis. Consequently, the process of finding the dimensions followed an iterative manner. The final dimensions that serve as the white spot analysis framework can be found in Table 2 and Table 3.

\subsection{Data Set}

The empirical basis for the white spot analysis is a sample of 188 "logistics platforms" that were identified by a structured web-based search using different search engines and iterations as outlined in Table 1.

Table 1: Sample selection

\begin{tabular}{|c|l|l|}
\hline \multicolumn{2}{|c|}{ Research Step } & \multicolumn{1}{c|}{ Outcome / Specification } \\
\hline $\mathbf{1}$ & $\begin{array}{l}\text { Database } \\
\text { Selection }\end{array}$ & $\begin{array}{l}\text { AngelList } \\
\text { Capterra } \\
\text { SourceForge }\end{array}$ \\
\hline $\mathbf{2}$ & $\begin{array}{l}\text { Search } \\
\text { Words }\end{array}$ & $\begin{array}{l}\text { platform AND logistics } \\
\text { logistics AND platform } \\
\text { platform AND SCM }\end{array}$ \\
\hline $\mathbf{3}$ & $\begin{array}{l}\text { Selected } \\
\text { Categories } \\
\text { in Database }\end{array}$ & $\begin{array}{l}\text { logistics platform } \\
\text { logistics software } \\
\text { logistics AND platform } \\
\text { platform AND logistics } \\
\text { logistics AND software }\end{array}$ \\
\hline $\mathbf{4}$ & $\begin{array}{l}\text { Initial } \\
\text { Selection }\end{array}$ & 171 Platforms \\
\hline $\mathbf{5}$ & $\begin{array}{l}\text { Further Web } \\
\text { Search }\end{array}$ & 17 Additional Platforms \\
\hline $\mathbf{6}$ & $\begin{array}{l}\text { Total } \\
\text { Sample }\end{array}$ & 188 Platforms in Total \\
\hline $\mathbf{7}$ & $\begin{array}{l}\text { Final } \\
\text { Selection }\end{array}$ & 54 Actual Platforms \\
\hline
\end{tabular}

The regional scope was not restricted and most platforms are from USA, Europe but also partly countries such as India or Canada. However, only platforms with information available in English language were considered. The corresponding results were transferred into an Excel spreadsheet in order to structure and analyze the results. In a next step, the homepages of the "platform providers" were again critically assessed with respect to the question whether the "platform" was a true platform or merely a software provider. Of those 188 "platforms" only 54 "platforms" were considered to be true digital platforms, meaning that they are connecting at least two distinct market sides given the information on the homepages. Digital offerings and services that merely provide an interface used by one distinct group in order to facilitate interaction with only the providing firm, were not considered to be platforms. Those were for instances online applications or portals for customers who seek information about their delivery or drivers that wish to manage their assigned 
transportation routes. Likewise, software-as-a-service business models were not considered to be platforms.

\subsection{Logistics Dimensions}

In logistics many different concepts and structuring frameworks can be found. Therefore, an initial set of different aspects and categories of logistics was identified along the previous literature discussion. The criteria were checked against the data set in order to assess suitability for the following white spot analysis. The first check of the homepages of the platforms indicated that rather a task-orientated approach would be suitable unlike dimensions of logistical domains or industries. Consequently, the final dimensions of the white spot analysis framework were reduced to the essential tasks of logistics as outlined in Table 2 following the compact definition of [37].

Table 2: Dimensions of logistics

\begin{tabular}{|l|l|}
\hline Logistical Task & \multicolumn{1}{|c|}{ Description } \\
\hline $\begin{array}{l}\text { Storage, } \\
\text { Warehousing } \\
\text { Handling [37 p. } \\
253 \mathrm{ff} \text {.] }\end{array}$ & $\begin{array}{l}\text { Provision and management of } \\
\text { warehouses and organization } \\
\text { of storage, structuring of goods } \\
\text { and related short-distance } \\
\text { movements of materials }\end{array}$ \\
\hline $\begin{array}{l}\text { Packaging and } \\
\text { Unitization [37 } \\
\text { p. 566 ff.] }\end{array}$ & $\begin{array}{l}\text { Packaging and labelling as } \\
\text { well as product preparation }\end{array}$ \\
\hline $\begin{array}{l}\text { Inventory [37 } \\
\text { p. 191 ff.] }\end{array}$ & $\begin{array}{l}\text { Monitoring and management } \\
\text { of stocks such as raw materials, } \\
\text { in-process stocks, finished } \\
\text { products, pipeline stocks, } \\
\text { general stocks and spare parts }\end{array}$ \\
\hline $\begin{array}{l}\text { Transportation of goods via air, } \\
\text { Transportation } \\
\text { [37 p. 365 ff.] }\end{array}$ & $\begin{array}{l}\text { road, sea and rail and related } \\
\text { services }\end{array}$ \\
\hline $\begin{array}{l}\text { Information } \\
\text { and Control } \\
\text { [37 p. 503 ff.] }\end{array}$ & $\begin{array}{l}\text { Activities and services that } \\
\text { deal with optimizing the } \\
\text { supply chain and the logistics } \\
\text { process such as data analysis, } \\
\text { forecasting, cost and } \\
\text { performance monitoring, } \\
\text { automatic payments etc. }\end{array}$ \\
\hline
\end{tabular}

\subsection{Platform Dimensions}

Analogously to the logistical tasks, different characteristics of digital B2C platforms were derived from the according literature discussion with respect to platforms and ecosystems. After a first empirical check and whether information was assessable, the characteristics outlined in Table 3 were chosen in order to structure the framework of the white spot analysis. The final dimensions are divided into three main themes with different sub-dimensions. Thereby, the final dimensions are rather general and can be applied independently of the respective industry or branch. The identified dimensions are the essentials of platform standard literature and often used in the standard B2C- and C2C literature in order to describe and explain the functioning of digital platforms and ecosystems.

Table 3: Dimensions of digital platforms

\begin{tabular}{|c|c|}
\hline $\begin{array}{l}\text { Platform } \\
\text { Characteristics }\end{array}$ & Description \\
\hline $\begin{array}{l}\text { Interacting } \\
\text { Parties [25] } \\
\text { - } \quad \text { Two-sided } \\
\quad \text { Platform } \\
\text { - } \quad \text { Multisided } \\
\quad \text { Platform }\end{array}$ & $\begin{array}{l}\text { Amount of interacting parties: } \\
\text { platform provider and two } \\
\text { market sides that are matched } \\
\text { (two-sided) or platform } \\
\text { provider, two interacting } \\
\text { market sides and a third party } \\
\text { (multisided). }\end{array}$ \\
\hline $\begin{array}{l}\text { Type of } \\
\text { Platform [2, } \\
\text { 27] } \\
\text { - } \quad \text { Innovation } \\
\quad \text { Platform } \\
\text { - } \quad \text { Transaction } \\
\quad \text { Platform } \\
\text { - } \quad \text { Hybrid } \\
\quad \text { Platform }\end{array}$ & $\begin{array}{l}\text { Platforms that are providing } \\
\text { technological building blocks } \\
\text { and digital infrastructure for } \\
\text { other companies and } \\
\text { developers that connect with } \\
\text { customers (innovation) or } \\
\text { platforms that are facilitating } \\
\text { transactions or exchange of } \\
\text { information (transaction) or } \\
\text { platforms doing both (hybrid). }\end{array}$ \\
\hline $\begin{array}{l}\text { Comple- } \\
\text { mentary } \\
\text { Services [30] } \\
\text { - } \quad \text { External } \\
\quad \text { Comple- } \\
\quad \text { ments } \\
\text { - Internal } \\
\text { Additional } \\
\text { Services }\end{array}$ & $\begin{array}{l}\text { Open external contribution of } \\
\text { digital complements increasing } \\
\text { the value of the platform } \\
\text { (external complements) unlike } \\
\text { a third-party side being } \\
\text { integrated by e.g. its own API's } \\
\text { or additional features offered } \\
\text { by the platform provider itself } \\
\text { (internal additional services). }\end{array}$ \\
\hline
\end{tabular}

\subsection{Results}

In order to derive whether the identified criteria were applicable or not, information from the homepages of the according 54 platforms were analyzed in depth and structured against the derived dimensions. The results are shown in Table 4. 
Table 4: White spot analysis of digital platforms in logistics $(n=54)$

\begin{tabular}{|c|c|c|c|c|c|c|c|}
\hline & \multicolumn{2}{|c|}{ Interacting Parties } & \multicolumn{3}{|c|}{ Type of Platform } & \multicolumn{2}{|c|}{$\begin{array}{c}\text { Complementary } \\
\text { Services }\end{array}$} \\
\hline & Two-sided & $\begin{array}{l}\text { Multi- } \\
\text { sided }\end{array}$ & $\begin{array}{l}\text { Inno- } \\
\text { vation }\end{array}$ & $\begin{array}{l}\text { Trans- } \\
\text { action }\end{array}$ & Hybrid & $\begin{array}{c}\text { External } \\
\text { Comple- } \\
\text { ments } \\
\end{array}$ & $\begin{array}{c}\text { Internal } \\
\text { Additional } \\
\text { Services }\end{array}$ \\
\hline 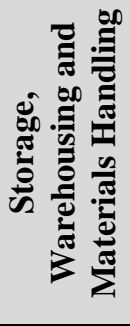 & $\begin{array}{l}\text { Stowga } \\
\mathrm{n}=1\end{array}$ & $\begin{array}{l}\text { Easyship, } \\
\text { FourKites, } \\
\text { Getbyrd, } \\
\text { Stord } \\
\mathrm{n}=10\end{array}$ & & $\begin{array}{l}\text { Getbyrd, } \\
\text { Stord, } \\
\text { Stowga } \\
\mathrm{n}=3\end{array}$ & $\begin{array}{l}\text { Easyship, } \\
\text { FourKites } \\
\mathrm{n}=8\end{array}$ & & $\begin{array}{l}\text { Easyship, } \\
\text { FourKites, } \\
\text { Getbyrd, } \\
\text { Stord, } \\
\text { Stowga } \\
\mathrm{n}=11\end{array}$ \\
\hline 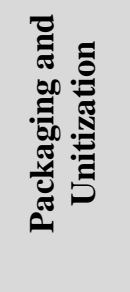 & $\begin{array}{l}\text { INFr8 } \\
\mathrm{n}=1\end{array}$ & $\begin{array}{l}\text { Getbyrd, } \\
\text { Shipfusion, } \\
\text { Shippo, } \\
\text { Shipwire } \\
\text { n }=8\end{array}$ & $\begin{array}{c}\text { White Spot } \\
2\end{array}$ & $\begin{array}{l}\text { Getbyrd, } \\
\text { INFr8 } \\
\mathrm{n}=2\end{array}$ & $\begin{array}{l}\text { Shipfusion, } \\
\text { Shippo, } \\
\text { Shipwire } \\
\mathrm{n}=7\end{array}$ & & $\begin{array}{l}\text { Getbyrd, } \\
\text { INFr8, } \\
\text { Shipfusion, } \\
\text { Shippo, } \\
\text { Shipwire } \\
\text { n=9 }\end{array}$ \\
\hline$\stackrel{\overrightarrow{0}}{\stackrel{0}{0}}$ & $\begin{array}{c}\text { White Spot } \\
1\end{array}$ & $\begin{array}{l}\text { Getbyrd, } \\
\text { Shipfusion, } \\
\text { Shippo, } \\
\text { Shipwire, } \\
\text { W3bstore } \\
\text { n = }\end{array}$ & & $\begin{array}{l}\text { Getbyrd, } \\
\text { W3bstore } \\
\mathrm{n}=2\end{array}$ & $\begin{array}{l}\text { Shipfusion, } \\
\text { Shippo, } \\
\text { Shipwire } \\
\mathrm{n}=6\end{array}$ & $\begin{array}{c}\text { White Spot } \\
3\end{array}$ & $\begin{array}{l}\text { Getbyrd, } \\
\text { Shipfusion, } \\
\text { Shippo, } \\
\text { Shipwire, } \\
\text { W3bstore } \\
\text { n=8 }\end{array}$ \\
\hline 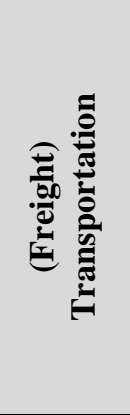 & $\begin{array}{l}\text { 2ships, } \\
\text { AX4, } \\
\text { FR8Star, } \\
\text { Shipwell } \\
\mathrm{n}=20\end{array}$ & $\begin{array}{l}\text { Evan } \\
\text { Network, } \\
\text { Getbyrd, } \\
\text { IBM Food } \\
\text { Trust, } \\
\text { Provenance, } \\
\text { Tradelens } \\
\mathrm{n}=32\end{array}$ & $\begin{array}{l}\text { Evan } \\
\text { Network, } \\
\text { IBM Food } \\
\text { Trust, } \\
\text { Provenance, } \\
\text { Tradelens } \\
\mathrm{n}=4\end{array}$ & $\begin{array}{l}\text { FR8Star, } \\
\text { Getbyrd } \\
\mathrm{n}=25\end{array}$ & $\begin{array}{l}\text { 2ships, } \\
\text { AX4, } \\
\text { Shipwell } \\
\mathrm{n}=24\end{array}$ & & $\begin{array}{l}\text { 2ships, } \\
\text { AX4, } \\
\text { Evan } \\
\text { Network, } \\
\text { Getbyrd, } \\
\text { IBM Food } \\
\text { Trust, } \\
\text { Provenance, } \\
\text { Shipwell, } \\
\text { Tradelens } \\
\mathrm{n}=45\end{array}$ \\
\hline ن & $\begin{array}{l}\text { 2ships, } \\
\text { AX4, } \\
\text { INFr8, } \\
\text { Shipwell } \\
\mathrm{n}=15\end{array}$ & $\begin{array}{l}\text { Evan } \\
\text { Network, } \\
\text { IBM Food } \\
\text { Trust, } \\
\text { Provenance, } \\
\text { Tradelens } \\
\\
\mathrm{n}=30\end{array}$ & $\begin{array}{l}\text { Evan } \\
\text { Network, } \\
\text { IBM Food } \\
\text { Trust, } \\
\text { Provenance, } \\
\text { Tradelens } \\
\\
\mathrm{n}=4\end{array}$ & $\mathrm{n}=17$ & $\begin{array}{l}\text { 2ships, } \\
\text { AX4, } \\
\text { Shipwell } \\
\text { n }=24\end{array}$ & & $\begin{array}{l}\text { 2ships, } \\
\text { AX4, } \\
\text { Evan } \\
\text { Network, } \\
\text { IBM Food } \\
\text { Trust, } \\
\text { INFr8, } \\
\text { Provenance, } \\
\text { Shipwell } \\
\mathrm{n}=44\end{array}$ \\
\hline
\end{tabular}


For better graphical display, only a limited number of digital platforms was transferred whereas the total number of platforms in the certain category is displayed at the bottom of the cell. In general, platforms can be identified in all logistics dimensions. The most popular platform types are transportation platforms followed by information and control.

Thereby, information and control are mostly linked to transport or warehousing.

Most platforms offer additional functions and features such as visibility, tracking and tracing, planning tools or smart data analysis and therefore serve the logistical task of information and control. Likewise, a lot of platforms offer services that are related to warehousing and storage by either bringing together warehouse providers and storage seekers or offering own warehouses. In addition, packaging and unitization is offered along with warehousing or inventory management. Thereby, packaging and unitization tasks can be confined to labelling but also be a part of complete logistics fulfillment service. Along with such fulfillment services, inventory planning and monitoring if often provided.

The majority of the observed platforms can be characterized as multisided platforms. Two-sided platforms are mostly found in the dimension of transportation whereas a two-sided inventory platform was not found within the sample at all (white spot 1). However, inventory is mostly an element of general logistics fulfillment platforms and does not really function in isolation. The identified multisided platforms often bring together logistics service providers such as haulage contractors as one market side and sending parties as the other market side. Some platforms add second-party or first-party logistics providers such as simple shippers as a third market side. Most platforms also add warehouses or warehouse providers, too. However, the most common type of multisided platform are e-commerce service platforms such as Getbyrd or Shippo. These are platforms that connect e-commerce shop owners with transportation companies and also provide APIs and integration services for other digital marketplaces such as eBay or e-commerce software providers like Shopify. Other multisided platforms serve the same idea but focus more on B2B end-customers. For example, FourKites offers fulfillment services such as transportation via integrated partners, warehouses and also integration into established software systems from SAP, IBM and Oracle. Due to the fact, that most multisided platforms offer fulfillment services they appear in all logistical dimensions. Most of these platforms can also be viewed as hybrid platforms. They were classified as such when they provided APIs and software development kits for firms in order to integrate the platform solutions. Consequently, those platforms partially provide software and infrastructure.

However, only few and pure innovation platforms could be identified. The platforms identified were assigned to transportation and information and control. In the other dimensions, pure innovation platforms were not found. This leads to the identification of white spot 2 . Though, all of those platforms labelled as innovation platforms were blockchain-based solutions and thus may be seen as special cases. Those blockchain solutions can be seen as innovation platforms in the sense that they provide a technological infrastructure, a network solution based on the blockchain technology, upon which other companies participate in a decentralized network-based exchange of information and data. At the same time, blockchain-based platforms could also be viewed as software-as-a-service providers and are therefore somehow ambiguous with respect to the interpretation of platform characteristics.

Closely linked with the underrepresentation of innovation platforms, is the provision of complementary goods and services. None of the identified platforms provide external, complementary services. Although platforms provide APIs or partially software development kits, they do not allow for independent, non-contractual external complementary provision on their very own platform. By complementary provision, especially digital assets such as apps or other digital products in the sense of B2C platforms are meant. To be distinguished therefrom, is the integration of a third market side such as another e-commerce platform or a transportation service. The integration of a third market side may enhance the platforms value but is different from complementary goods and service provision in the sense that platform technology is not used in order to provide new and innovative products or services. Providers of complementary goods and services rather compete with each other and try to develop unique, innovative products setting themselves apart from competition [29]. In contrast, transportation services are merely to be distinguished via the price and the availability respectively modality.

Indeed, those platforms that connect e-commerce services with transportation and/or warehousing could rather be seen as complements to the original platforms as e.g. Amazon provides the initial API allowing for integration into its platform. Thus, the open integration of additional (digital) products and services that are externally provided, is not observed within the underlying sample. Consequently, white 
spot 3 is observed in the dimension of external complements along all logistics dimensions.

Nevertheless, platforms often offer applications within an app store provided by e.g. Apple or Android or provide additional, distinct services and features such as payment solutions or planning tools. However, these services and applications are either offered by the platform provider itself - eventually even under a different company name but within the same legal entity - or are exclusively integrated and contracted as a third party. Therefore, external provision of digital complementary services in the sense of B2C platforms such as Google, Apple or Philipps Hue where companies, start-up and private developers can build and provide own solutions on that very platform is not observed.

\section{Discussion}

The identified platforms and their characteristics are in line with e.g. [43] who identified digital transportation marketplaces, global fulfillment, forwarding service platforms and warehousing platforms to be amongst the most common archetypes of digital business models in logistics. Likewise, [18] describe digital forwarding platforms offering a full services in the sense of the fulfillment platforms identified above. In addition, [45] discuss 57 crowdlogistics initiatives, that are mostly digital platforms serving the purposes of freight forwarding and shipping, local delivery and storage. In addition, the underlying white spot analysis also identifies platforms linking fulfillment services with the integration of additional partners such as technology partners or other e-commerce shops. Thereby, those platforms could be viewed as a complement to the original platform respectively as a part of the original ecosystem.

However, as already outlined, the integration of external APIs cannot be viewed as an external contribution in the sense of "true" complementary digital services and products. In the sense of B2C- or C2C platforms external complements are provided on a non-contractual, free and now and again decentralized manner allowing for self-evolving ecosystems. Such an integration of external complementary goods and services is not observed in the underlying analysis as indicated by white spot 2 and white spot 3 . The low representation of innovation platforms that provide technological building blocks may be strongly linked with the lack of complementary provision. If technology was openly provided, other companies and start-ups could use those technology and build own services and products that could be offered on the original platform. Though, this kind of exploitation of indirect network effects is not observed within the sample.

Therefore, the white spot analysis may indicate a lack of transferability of B2C platform principles towards digital platforms in industrial logistics. However, especially the logistics sector and supply chain management in general entail great potential for joint innovation creation in the context of digital transformation and new technologies such as distributed ledger technologies, IoT and artificial intelligence [36]. Though, retrieved data are mostly processed in a closed manner and constitute an essential aspects of most platform's business model in the sense of providing additional services in the field of information and control.

This may lead to several conclusions: On the one hand, B2B platforms could be substantially different from $\mathrm{B} 2 \mathrm{C}$ platforms with respect to their ability and willingness to openly share essential technology and data in order to integrate complementary goods and services. Therefore, B2C- or C2C platform principles may not be fully observable in practice respectively may not be transferable. Consequently, it would be necessary to derive new and unique B2B characteristics in order to describe logistics platforms independently from B2C characteristics. On the other hand, it may also be possible that those principles could be transferred but that platform providers fail to fully exploit the potentials for building innovationdriven ecosystems. Possible reasons could be the according complexity of the business model and the evolving ecosystem, the high risk associated with such an openness in a B2B context and the fear of competitive disadvantages [46, 47].

\section{Conclusion, Limitations and Outlook}

The underlying paper contributes to the discussion of digital platforms in the context of logistics by explicitly addressing the question whether principles of B2C platforms can be observed in the context of B2B logistics platforms. Thereby, the paper identifies a gap with respect to innovation platforms, digital complements and the related indirect network effects. Thus, the respective white spot analysis provides a first indicator that not all platform principles of B2C platforms can be easily observed respectively be applied in order to describe logistics platforms in a B2B context. In specific, the white spot analysis indicates that innovation platforms are underrepresented and that digital B2B platforms in logistics might be unable to openly integrate complementary digital assets. However, the paper is subject to limitations. At first, the underlying sample only consist of 54 platforms and the classification with 
respect to complementary goods and services might be interpreted differently. Likewise, the sample mainly focused on digital platforms in the assigned logistical dimensions. Other platforms could eventually be found in the dimensions of IoT platforms, supply chain management or blockchain. However, blockchainplatforms constitute a special case and need separate considerations as the general platform characteristics discussed may actually not be fully applicable due to the overall discussion of decentralization and blockchain as remover of intermediaries.

Building upon the underlying findings, further research in the field of logistics platforms is recommended. At first, more platforms could be examined in order to check the robustness of the white spot analysis. Furthermore, the analysis and discussion of complements together with innovation platforms with respect to B2B logistics platforms has great potential for further research. Finally, the discussion whether B2C principles are sufficient to describe B2B platforms or whether own principles need to be derived should be continued by confronting empirical evidence with theoretical foundations for logistics and supply chain management.

\section{Acknowledgement}

This research was supported by the "Silicon Economy Logistics Ecosystem" funded by the German Federal Ministry of Transport and Digital Infrastructure.

\section{References}

[1] Henten, H.A. and M.I. Windekilde, "Transaction costs and the sharing economy", INFO, 18(1), 2016, pp. 1-15.

[2] Gawer, A., "Digital platforms' boundaries: The interplay of firm scope, platform sides, and digital interfaces", Long Range Planning, 2020, p. 102045.

[3] Loux, P., M. Aubry, S. Tran, and E. Baudoin, "Multisided platforms in $\mathrm{B} 2 \mathrm{~B}$ contexts: The role of affiliation costs and interdependencies in adoption decisions", Industrial Marketing Management, 84, 2020, pp. 212-223.

[4] Tian, J., J. Vanderstraeten, P. Matthyssens, and L. Shen, "Developing and leveraging platforms in a traditional industry: An orchestration and co-creation perspective", Industrial Marketing Management, 92, 2021, pp. 14-33.

[5] Abendroth, J., L. Riefle, and C. Benz, Opening the Black Box of Digital B2B Co-Creation Platforms: A Taxonomy, 2021.

[6] Svahn, F., L. Mathiassen, and R. Lindgren, "Embracing Digital Innovation in Incumbent Firms: How Volvo Cars Managed Competing Concerns", MIS Quarterly, 41(1), 2017, pp. 239-253.

[7] Dattée, B., O. Alexy, and E. Autio, "Maneuvering in Poor Visibility: How Firms Play the Ecosystem Game when
Uncertainty is High", Academy of Management Journal, 61(2), 2018, pp. 466-498.

[8] Lingens, B., L. Miehé, and O. Gassmann, "The ecosystem blueprint: How firms shape the design of an ecosystem according to the surrounding conditions", Long Range Planning, 2020, p. 102043.

[9] Hofmann, E. and F. Osterwalder, "Third-Party Logistics Providers in the Digital Age: Towards a New Competitive Arena?", Logistics, 1(2), 2017, p. 9.

[10] Atasoy, B., F. Schulte, and A. Steenkamp, "PlatformBased Collaborative Routing using Dynamic Prices as Incentives", Transportation Research Record: Journal of the Transportation Research Board, 2674(10), 2020, pp. 670679.

[11] Gruchmann, T., N. Pratt, J. Eiten, and A. Melkonyan, "4PL Digital Business Models in Sea Freight Logistics: The Case of FreightHub", Logistics, 4(2), 2020, p. 10.

[12] Agus, A.A., G. Yudoko, N. Mulyono, and T. Imaniya, "E-commerce Platform Performance, Digital Marketing and Supply Chain Capabilities", International Research Journal of Business Studies, 13, 2020, pp. 63-80.

[13] Zhang, M., G.Q. Huang, S.X. Xu, and Z. Zhao, "Optimization based transportation service trading in $\mathrm{B} 2 \mathrm{~B}$ ecommerce logistics", Journal of Intelligent Manufacturing, 30(7), 2019, pp. 2603-2619.

[14] Zhang, M., S. Pratap, G.Q. Huang, and Z. Zhao, "Optimal collaborative transportation service trading in B2B e-commerce logistics", International Journal of Production Research, 55(18), 2017, pp. 5485-5501.

[15] Rosano, M., C.G. Demartini, F. Lamberti, and G. Perboli, "A mobile platform for collaborative urban freight transportation", Transportation Research Procedia, 30, 2018, pp. 14-22.

[16] Schramm, H.-J., C.N. Czaja, M. Dittrich, and M. Mentschel, "Current Advancements of and Future Developments for Fourth Party Logistics in a Digital Future", Logistics, 3(1), 2019, p. 7.

[17] Haas, J. and M. Seiter, Selecting the right platform - the perspective of logistics service providers, Proceedings of the Hamburg International Conference of Logistics (HICL)(29), 2020.

[18] Mikl, J., D.M. Herold, M. Ćwiklicki, and S. Kummer, "The impact of digital logistics start-ups on incumbent firms : a business model perspective", The International Journal of Logistics Management, ahead-of-print(ahead-of-print), 2020, p. 1.

[19] Katz, M.L. and C. Shapiro, "Network Externalities, Competition, and Compatibility", The American Economic Review, 75(3), 1985, pp. 424-440.

[20] Katz, M.L. and C. Shapiro, "Systems Competition and Network Effects", Journal of Economic Perspectives, 8(2), 1994, pp. 93-115.

[21] Gawer, A. and M.A. Cusumano, "Industry Platforms and Ecosystem Innovation", Journal of Product Innovation Management, 31(3), 2014, pp. 417-433.

[22] McIntyre, D.P. and A. Srinivasan, "Networks, platforms, and strategy: Emerging views and next steps", Strategic Management Journal, 38(1), 2017, pp. 141-160.

[23] Hilbolling, S., H. Berends, F. Deken, and P. Tuertscher, "Complementors as connectors: managing open innovation 
around digital product platforms", R\&D Management, $\mathrm{n} / \mathrm{a}(\mathrm{n} / \mathrm{a}), 2019$.

[24] Adner, R., "Ecosystem as Structure", Journal of Management, 43(1), 2017, pp. 39-58.

[25] Tiwana, A., Platform ecosystems: Aligning architecture, governance, and strategy, Morgan Kaufmann, Waltham, MA, 2014.

[26] Hagiu, A. and J. Wright, "Multi-sided platforms", International Journal of Industrial Organization, 43(1), 2015, pp. 162-174.

[27] Cusumano, M.A., A. Gawer, and D.B. Yoffie, The Business of Platforms: Strategy in the Age of Digital Competition, Innovation, and Power, HarperCollins, 2019.

[28] Ghazawneh, A. and O. Henfridsson, "Balancing platform control and external contribution in third-party development: the boundary resources model", Information Systems Journal, 23(2), 2013, pp. 173-192.

[29] Cenamor, J., "Complementor competitive advantage: A framework for strategic decisions", Journal of Business Research, 122, 2021, pp. 335-343.

[30] Jacobides, M.G., C. Cennamo, and A. Gawer, "Towards a theory of ecosystems", Strategic Management Journal, 39(8), 2018, pp. 2255-2276.

[31] Hein, A., M. Schreieck, T. Riasanow, D.S. Setzke, M. Wiesche, M. Böhm, and H. Krcmar, "Digital platform ecosystems", Electronic Markets, 43(1), 2019, p. 39.

[32] Parker, G., M.W. van Alstyne, and X. Jiang, "Platform Ecosystems: How Developers Invert the Firm", SSRN Electronic Journal, 2016.

[33] Cennamo, C. and J. Santalo, "Platform competition: Strategic trade-offs in platform markets", Strategic Management Journal, 34(11), 2013, pp. 1331-1350.

[34] Zhu, F. and Q. Liu, "Competing with complementors: An empirical look at Amazon.com", Strategic Management Journal, 39(10), 2018, pp. 2618-2642.

[35]

https://cscmp.org/CSCMP/Educate/SCM_Definitions_and_ Glossary_of_Terms.aspx, accessed 5-24-2021.

[36] Winkelhaus, S. and E.H. Grosse, "Logistics 4.0: a systematic review towards a new logistics system", International Journal of Production Research, 58(1), 2020, pp. 18-43.

[37] Rushton, A., P. Croucher, and P. Baker, The Handbook of Logistics and Distribution Management: Understanding the Supply Chain, 5th edn., Kogan Page, London, 2014.

[38] Ketokivi, M. and J.T. Mahoney, "Transaction Cost Economics as a Theory of the Firm, Management, and Governance", in Oxford Research Encyclopedia of Business and Management, M. Ketokivi and J.T. Mahoney, Editors. 2017. Oxford University Press.

[39] Ketokivi, M. and J.T. Mahoney, "Transaction Cost Economics As a Theory of Supply Chain Efficiency", Production and Operations Management, 29(4), 2020, pp. 1011-1031.

[40] Zacharia, Z.G., N.R. Sanders, and N.W. Nix, "The Emerging Role of the Third-Party Logistics Provider (3PL) as an Orchestrator", Journal of Business Logistics, 32(1), 2011, pp. 40-54.

[41] Skjoett-Larsen, T., "Third party logistics - from an interorganizational point of view", International Journal of
Physical Distribution \& Logistics Management, 30(2), 2000, pp. 112-127.

[42] Baldwin, C.Y. and C.J. Woodard, "The Architecture of Platforms: A Unified View", SSRN Electronic Journal, 2008.

[43] Möller, F., H. Bauhaus, C. Hoffmann, C. Niess, and B. Otto, "ARCHETYPES OF DIGITAL BUSINESS MODELS IN LOGISTICS START-UPS", Proceedings of the 27th European Conference on Information Systems (ECIS), Stockholm \& Uppsala, Sweden, June 8-14, 2019.

[44] Cichosz, M., C.M. Wallenburg, and A.M. Knemeyer, "Digital transformation at logistics service providers: barriers, success factors and leading practices", The International Journal of Logistics Management, 31(2), 2020, pp. 209-238.

[45] Carbone, V., A. Rouquet, and C. Roussat, "The Rise of Crowd Logistics: A New Way to Co-Create Logistics Value", Journal of Business Logistics, 38(4), 2017, pp. 238252.

[46] Olsson, H.H. and J. Bosch, "Strategic Ecosystem Management: A Multi-case Study in the B2B Domain", in Product-Focused Software Process Improvement, P. Abrahamsson, L. Corral, M. Oivo, and B. Russo, Editors. 2015. Springer International Publishing: Cham.

[47] Olsson, H. and J. Bosch, "From ad hoc to strategic ecosystem management: the "Three-Layer Ecosystem Strategy Model" (TeLESM)", Journal of Software: Evolution and Process, 29(7), 2017, e1876. 